\title{
Conductive acrylic pressure-sensitive adhesives
}

\begin{abstract}
The paper presents the results of research on the impact of the amount of copper on acrylic pressure-sensitive adhesives. The effect of filler addition of $1.0-50.0 \% \mathrm{wt}$. on useful properties of adhesives was investigated. Increasing the amount of copper powder in the composition decreased adhesion and tack; cohesion and conductivity was increased. Conductive acrylic pressure-sensitive adhesives have been obtained.
\end{abstract}

Keywords: acrylic pressure-sensitive adhesives, conductive, adhesion, cohesion

\author{
Volume 9 Issue 2 - 2020
}

\author{
Adrian Krzysztof Antosik,' Nataniel Adrian \\ Antosik ${ }^{2}$ \\ 'Institute of Organic Chemical Technology, West Pomeranian \\ University of Technology Szczecin, Poland \\ IIT Institute, West Pomeranian University of Technology \\ Szczecin, Poland
}

\begin{abstract}
Correspondence: Adrian Krzysztof Antosik, Institute of Organic Chemical Technology, West Pomeranian University of Technology Szczecin, Poland,

Email adriankrzysztofantosi@gmail.com
\end{abstract}

Received: October 31, 2019 | Published: March 18, 2020

\section{Introduction}

Pressure-sensitive adhesives (PSAs) are non-metallic substances used to bond different materials. They are defined as adhesives that retain their adhesive properties when dry. Acrylate adhesives are one of the best known PSAs. ${ }^{1-4}$ Solvent-based acrylate pressuresensitive adhesives are produced by radical polymerization using a wide range of acrylate, methacrylate polymers and other monomers in an organic solvent in the presence of a thermal radical initiator such as organic peroxides or azo compounds. Solvent-based acrylic PSAs are characterized by good aging properties, high resistance to high temperature and plasticizers, and transparency. They also have a great balance between adhesion and cohesion, and excellent water resistance. The lower level of adhesion to non-polar polyolefin's is due to the relatively high polarity of polyacrylates..$^{5-9}$

The many advantages of solvent-based acrylic PSA have made these adhesives widely used in the production of self-adhesive products. They account for over $45 \%$ of the total number of PSAs produced. ${ }^{10}$ In order to obtain conductive acrylate pressure-sensitive adhesives, they are subjected to physical modification by introducing conductive fillers, such as metal particles (copper, aluminum), specially modified carbon black, carbon fibers, metallized glass and electrically conductive fibers, allows the creation of electrically conductive polymers with electrical conductivity from $10^{-2}$ to $10^{2} \mathrm{~S}$ / $\mathrm{cm}$. This relatively high conductivity is the result of the percolation of conductive filler particles in an insulating matrix or tunneling between electrically conductive particles. ${ }^{11-13}$

Since the acrylic PSA was introduced to the market half a century ago, they have been successfully used in many industries. They are used in mounting tapes, self-adhesive labels and protective films, decorative films, in the paper and electronics industry. In medicine they find us as a ends of biomedical electrodes using to contact with skin, tape to securing a surgical dressing, transparent dressings are widely used to cover and protect superficial wounds, they are included in plaster, pads and adhesive patches (including patches with transdermal medications) - transdermal drug delivery systems (TDDS), self-adhesive hydrogels and surgical drapes. ${ }^{5,11-15}$
In this paper influence of addition conductive filler (copper) on selfadhesives properties of acrylic pressure-sensitive adhesives were presented. Conductive adhesive tapes with varying degrees of filling were obtained for the tests. The materials thus obtained can be used, e.g. in medicine.

\section{Materials and methods}

\section{Materials}

Commercial resins, crosslinking agent, solvent, monomers and conductive filler selected for testing were collected in Table 1 .

\section{Preparation of acrylic PSA}

To study the effect of copper powder on the conductive and self-adhesive properties of the pilot acrylate composition, a base adhesive (containing BA, 2-EHA and AA) was synthesized (radical polymerization reaction), which was then modified with the addition of Derthophene 105 resin $(45 \% \mathrm{wt})$ and Tragum $2331 \mathrm{WS}(5 \% \mathrm{wt})$. To reduce the viscosity, $30 \% \mathrm{wt}$ isoproponol, containing $0.2 \mathrm{wt} \mathrm{AlACA}$ (cross-linking compound) was added. The composition thus obtained was mixed with $3,5,7,10,15,25,40$ or 50 parts, respectively. \%wt copper powder (calculated on the dry weight of the resin). The mixture prepared in this way was left for 24 hours for degassing, after which it was coated on a polyester film with a thickness of $36 \mu \mathrm{m}$ using an automatic coating machine developed in the Laboratory of Adhesives and Self-Adhesive Materials of the West Pomeranian University of Technology in Szczecin in order to obtain the same thickness of the adhesive layer over the entire surface. The coated film with the adhesive composition was cross linked for $10 \mathrm{~min}$ in a drying channel at $105^{\circ} \mathrm{C}$ (radical crosslinking reaction), and then the obtained adhesive layer was protected with siliconized paper. The basis weight of the pressure-sensitive adhesive layers tested was $45 \mathrm{~g} / \mathrm{m}^{2}$.

\section{Methods}

Acrylic pressure-sensitive adhesives based properties as peel cohesion, adhesion, and tack was measured by using machine designed at the Laboratory for Adhesives and Self-Adhesive Materials of the 
West Pomeranian University of Technology Szczecin and ZwickRoell Z1 machine (Germany) according to international standard Federation Internationale des Fabricants et Transformateurs dadhesifs et thermocollants sur papiers et autres support (FINAT) respectively FTM 8, FTM 1 and FTM 9

Table I Materials used for research

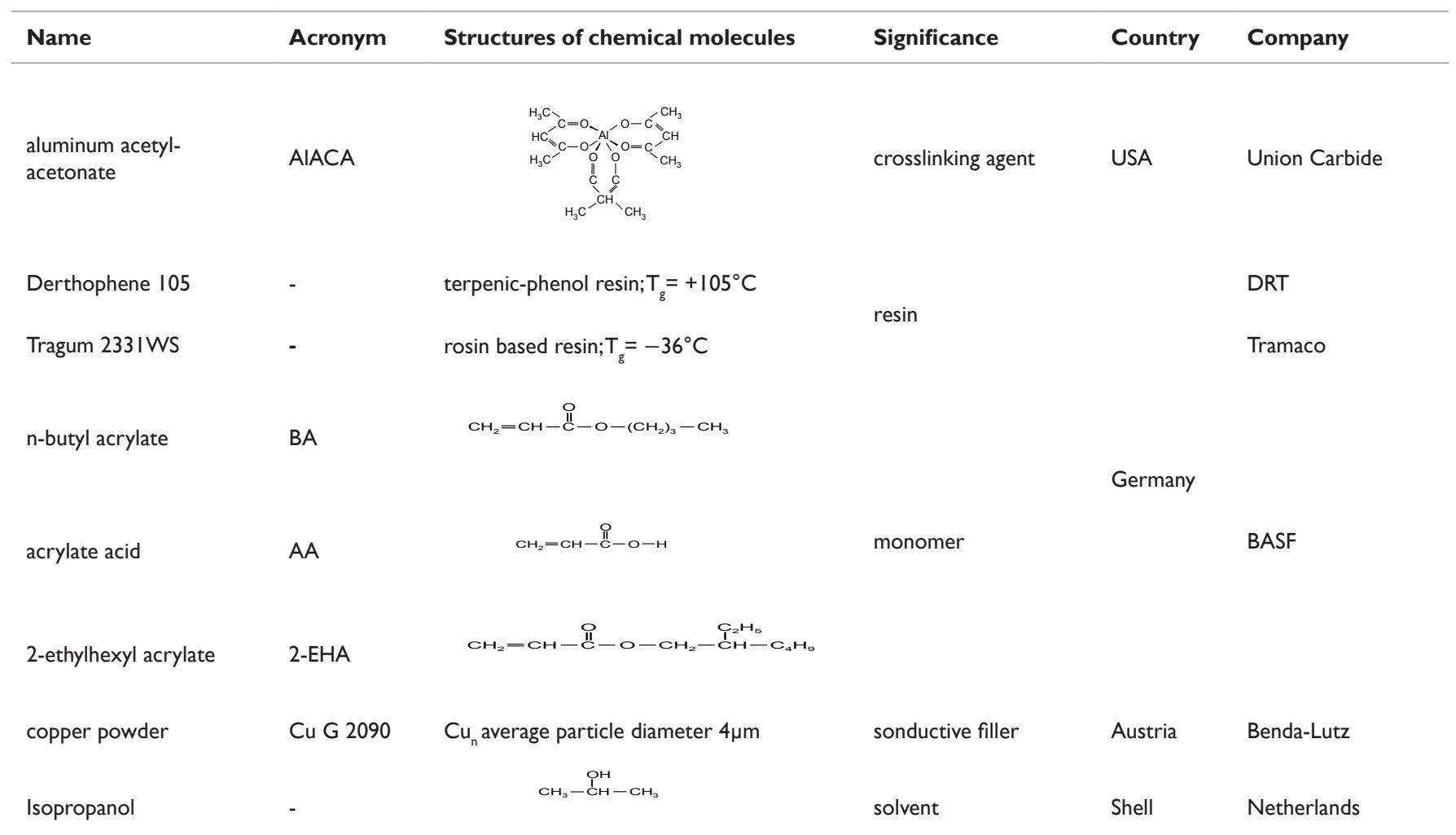

Electrical conductivity was measured according to the international DIN 53482 standard. Pot-life of acrylic pressure-sensitive adhesives compositions was measurement as a different in viscosity at time. Noncross linked adhesive compositions were tested at an interval of 1,2, $3,5,7,36,60$ and 90 days from receipt of the composition. Each time viscosity of silicone pressures-sensitive adhesives composition was determined with a RM 180 rotational viscometer from Rheometric Scientific, with spindle No 3 at temperature room.

\section{Results and discussion}

There was no effect of the amount of time on the viscosity of the "clean" adhesive composition. In the case of compositions containing small amounts of filler (from 1 to $8 \%$ wt.), significant increase in viscosity was noted after 8 days of preparation of the composition. The upper limit of compositions with conductive filler is $15 \% \mathrm{wt}$ copper powder, for such a composition a large increase in viscosity was noted, however, after 90 days they can still be coated. High-fill compositions rapidly increase viscosity and after a few days are not coatable (gel). After gelation, solvent-based acrylic PSAs containing copper powder are blue due to the formation of copper salts in the reaction between copper and carboxyl groups that are part of the polymeric acrylate chain. Copper powder in electrically conductive PSA easily absorbs water molecules. Slowly sedimented the copper powder during the study (Table 2).

Table $\mathbf{2}$ Impact of the additive copper powder on viscosity of acrylic PSA in time

\begin{tabular}{|c|c|c|c|c|c|c|c|c|c|}
\hline \multirow[t]{2}{*}{ Content of filler [\%wt.] } & \multicolumn{9}{|c|}{ Viscosity [Pas] } \\
\hline & $\mathbf{O h}$ & $24 \mathrm{~h}$ & 2 days & 3 days & 5 days & 8 days & 30 days & 60 days & 90 days \\
\hline 0 & 1.2 & 1.2 & 1.2 & 1.2 & 1.2 & 1.2 & 1.2 & 1.2 & 1.2 \\
\hline 1 & 1.2 & 1.2 & 1.2 & 1.2 & 1.2 & 1.2 & 1.3 & 1.5 & 1.7 \\
\hline 3 & 1.2 & 1.2 & 1.2 & 1.2 & 1.2 & 1.3 & 1.7 & 2.1 & 2.8 \\
\hline 5 & 1.2 & 1.2 & 1.2 & 1.3 & 1.4 & 1.5 & 2 & 2.5 & 3.4 \\
\hline 7 & 1.2 & 1.3 & 1.3 & 1.3 & 1.5 & 2 & 3.1 & 4.6 & 6.7 \\
\hline 10 & 1.4 & 1.4 & 1.4 & 1.4 & 1.6 & 3 & 5.2 & 7.9 & 10.8 \\
\hline 15 & 1.5 & 1.5 & 1.5 & 1.5 & 1.7 & 4.1 & 7.1 & 10.3 & 13.8 \\
\hline 25 & 1.6 & 1.6 & 1.6 & 1.9 & 2.4 & 10.3 & gel & gel & gel \\
\hline 40 & 1.9 & 1.9 & 2 & 3.1 & 9.8 & 16.9 & gel & gel & gel \\
\hline 50 & 2.3 & 2.9 & 3.2 & 4.6 & 14.8 & gel & gel & gel & gel \\
\hline
\end{tabular}


The addition of a conductive filler (copper powder) in acrylic pressure-sensitive adhesive compositions decreased in the value of adhesion, cohesion and tack (Table 3 \& Figure 1). This is especially visible for large fillers (40 and 50 parts by weight of copper powder). Adhesive cracks (during cohesion tests) show that the adhesive and cohesive balance of the composition has been shifted significantly towards cohesion. The increase in the amount of filler increased the conduction of adhesive films (when filling 50 parts by weight, the conductivity was $91 \mathrm{~S} / \mathrm{cm})$.

Table 3 Impact of the additive copper powder on cohesion and electric conductive of acrylic PSA

\begin{tabular}{lll}
\hline Content of filler [\% wt] & Cohesion $[\mathrm{h}]$ & $\begin{array}{l}\text { Electric conductive } \\
{[\text { S/cm }]}\end{array}$ \\
\hline 0 & $>72$ & $1.2 \cdot 10^{-11}$ \\
1 & $>72$ & $1.8 \cdot 10^{-11}$ \\
3 & $>72$ & $2.2 \cdot 10^{-11}$ \\
5 & $>72$ & $2.5 \cdot 10^{-11}$ \\
7 & $>72$ & $3.7 \cdot 10^{-11}$ \\
10 & $>72$ & $3.3 \cdot 10^{-9}$ \\
15 & 68 & $6.3 \cdot 10^{-2}$ \\
25 & 55 & $5.5 \cdot 10^{-1}$ \\
40 & 49 & $1.1 \cdot 10^{1}$ \\
50 & 26 & $9.2 \cdot 10^{1}$ \\
\hline
\end{tabular}

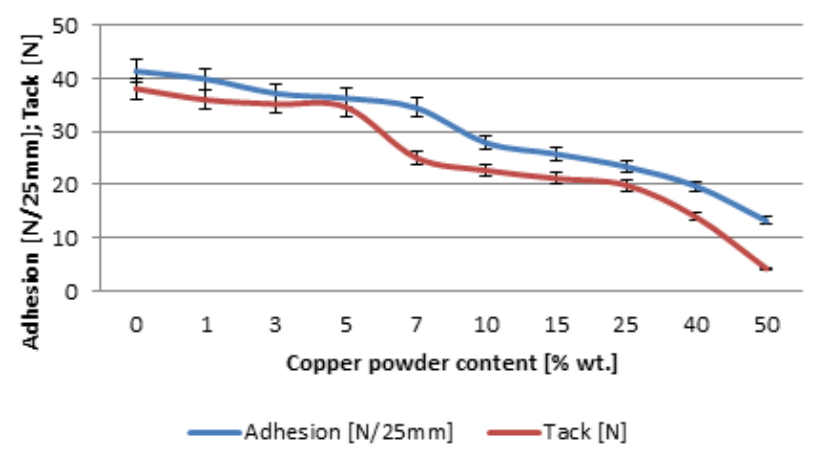

Figure I Impact of the additive copper powder on adhesion and tack of acrylic PSA.

\section{Conclusion}

Conductive compositions based on solvent-based acrylic pressuresensitive adhesives with copper powder with a characteristic copper color were obtained. With the increase of the conductive filler in the adhesive composition based on synthesized acrylic pressure-sensitive adhesive subjected to modification, the usable properties of adhesive films such as tack and adhesion to steel deteriorate. On the other hand, the cohesive properties, current conduction and viscosity of the tested adhesive compositions increased with the increase in the amount of copper powder.

Despite a significant reduction in the performance of the tested samples, in most cases they meet the basic performance requirements of adhesive tapes. ${ }^{10}$ In the case of tapes with the highest fillings, the cohesion time deviated from the accepted standards of maintaining above 72 hours at a load of $1 \mathrm{~kg}$, however, due to the specificity of potential applications of conductive tapes based on copper powder compositions. The obtained compositions were characterized by relatively high electrical conductivity.

\section{Acknowledgements}

None.

\section{Conflicts of interest}

The author declares that there are no conflicts of interest.

\section{Funding}

None.

\section{References}

1. Antosik A, Mozelewska K, Czech Z, et al. Influence of montmorillonite on the properties of silicone pressure-sensitive adhesives: preparation of double-sided type based on the best composition. Silicone. 2019;1-7.

2. Czech Z, Malec A, Czech Z, et al. Synteza i zastosowanie rozpuszczalnych w wodzie klejów samoprzylepnych na bazie poliakrylanów. Przemyst Chemiczny. 2006;85(11):1488-1494.

3. Czech Z, Kowalczyk A, Gąsiorowska M, et al. Novel pyridinium derivatives as very efficient photoinitiators for UV-activated synthesis of acrylic pressure-sensitive adhesives. International Journal of Adhesion and Adhesives. 2011;31(7):634-638.

4. Antosik A, Czech Z. Wpływ ilości barwnika na fizyczne właściwości silikonowych klejów samoprzylepnych. Przemyst Chemiczny. 2015;94(1):41-42.

5. Czech Z. Crosslinking of pressure sensitive adhesives on water-born acrylate. Polymer International. 2003;52(3):347-357.

6. Singh BP, Jana BK, Bhattacharjee S, et al. Development of oxidation and corrosion resistance hydrophobic graphene oxide-polymer composite coating on copper. Surface and Coatings Technology. 2013;232:475-481.

7. Park GH, Kim T, Ahn YT, et al. The effects of graphene on the properties of acrylic pressure-sensitive adhesive. Journal of Industrial and Engineering Chemistry. 2014;20:4108-4111.

8. Czech Z, Butwin A. Poliakrylanowe kleje samoprzylepne sieciowane dualnie. Wiadomości Chemiczne. 2009;63(3-4):269-284.

9. Zhu M, Cao Z, Zhou H, et al. Preparation of environmentally friendly acrylic pressure-sensitive by bulk photopolymerization and their performance. Royal of Society of Chemistry. 2020;10:10277-10284.

10. Czech Z, Milker R. Development trends in pressure-sensitive adhesive systems. Materials Science-Poland. 2005;23:1015-1022.

11. Czech Z, Kowalczyk A, Shao S, et al. Novel acrylic pressure-sensitive adhesive (PSA) containing silver particles. Journal of Adhesion Science and Technology. 2013;27:1446-1454.

12. Lee JH, Lee DW. Contact-induced molecular rearrangement of acrylic acid-incorporated pressure sensitive adhesives. Applied Surface Science. 2020;500:144246.

13. Vu MC, Bae YH, Yu MJ, et al. Thermally conductive adhesives from covalent-bonding of reduced grapheme oxide to acrylic copolymer. The Journal of Adhesion. 2019;95(10):887-910.

14. Antosik AK, Bednarczyk P, Czech Z. Jednostronnie klejące taśmy na bazie samoprzylepnych klejów silikonowych - dobór najlepszej kompozycji. Chemik. 2015;69(12):95-97.

15. Lee JH, Shim GS, Kim HJ, et al. Adhesion performance and recovery of acrylic PSA with acrylic elastomer (AE) blends via thermal crosslinking for application in flexible displays. Polymers. 2019;11(12):1959. 